University of Nebraska - Lincoln

DigitalCommons@University of Nebraska - Lincoln

Publications, Agencies and Staff of the U.S.

Department of Commerce

U.S. Department of Commerce

7-1998

Seasonal Variation in Reception of Fin Whale Calls at Five Geographic Areas in the North Pacific

Follow this and additional works at: https://digitalcommons.unl.edu/usdeptcommercepub

Part of the Environmental Sciences Commons

"Seasonal Variation in Reception of Fin Whale Calls at Five Geographic Areas in the North Pacific" (1998). Publications, Agencies and Staff of the U.S. Department of Commerce. 175.

https://digitalcommons.unl.edu/usdeptcommercepub/175

This Article is brought to you for free and open access by the U.S. Department of Commerce at DigitalCommons@University of Nebraska - Lincoln. It has been accepted for inclusion in Publications, Agencies and Staff of the U.S. Department of Commerce by an authorized administrator of DigitalCommons@University of Nebraska - Lincoln. 
MARINE MAMMAL SCIENCE, 14(3):617-627 (July 1998)

(C) 1998 by the Society for Marine Mammalogy

\section{SEASONAL VARIATION IN RECEPTION OF FIN WHALE CALLS AT FIVE GEOGRAPHIC AREAS IN THE NORTH PACIFIC}

In late August 1991 scientists at the National Oceanic and Atmospheric Administration's (NOAA) National Marine Mammal Laboratory (NMML) and Pacific Marine Environmental Laboratory (PMEL) began a pilot study to investigate the capability of hydrophones from the U.S. Navy's fixed array system to detect large whales in the North Pacific by passive reception of their calls. PMEL had previously established a direct data link from five bottom-mounted arrays of the Navy SOSUS (SOund SUrveillance System), via the Naval Oceanographic Processing Facility (NOPF) at Whidbey Island, Washington, to study low-level seafloor seismicity (Fox et al. 1994). PMEL subsequently provided NMML tapes of SOSUS hydrophone data from which whale calls were analyzed. As in an analogous study conducted in the North Atlantic (Nishimura and Conlon 1994, Clark 1995, Mellinger and Clark 1995), calls attributable to whales were received at each SOSUS site at rates that varied seasonally (Anonymous 1996).

Pulsed signals, similar to those recorded from fin whales (Balaenoptera physalus), were the most distinctive of the whale calls received during the pilot study. In addition to other sounds, fin whales produce characteristic, loud, short calls termed "20-Hz pulses" (Watkins 1981). These signals are roughly $1 \mathrm{sec}$ long, with energy concentrated near $20 \mathrm{~Hz}$ and source levels of $\sim 160$ $186 \mathrm{~dB}$ re $1 \mu \mathrm{Pa}-\mathrm{m}$ (reviewed in Thomson and Richardson 1995). Such pulses are produced in: (1) long stereotyped bouts, composed of repeated series of either single or "doublet" pulses with regular interpulse intervals, and (2) comparatively short series with irregular interpulse intervals. The long bouts $(<1-32.5 \mathrm{~h})$ of stereotyped calling by individual whales are thought to be reproductive displays (Watkins et al. 1987, Thompson et al. 1992), while the shorter irregular pulse sequences $(\leq 5 \mathrm{~min}$ ) are produced in series by a number of different whales and have been associated with feeding, socializing, and transiting animals (Watkins 1981, McDonald et al, 1995). Calls attributed to fin whales during the pilot study had peak energy centered near $20 \mathrm{~Hz}$ and 


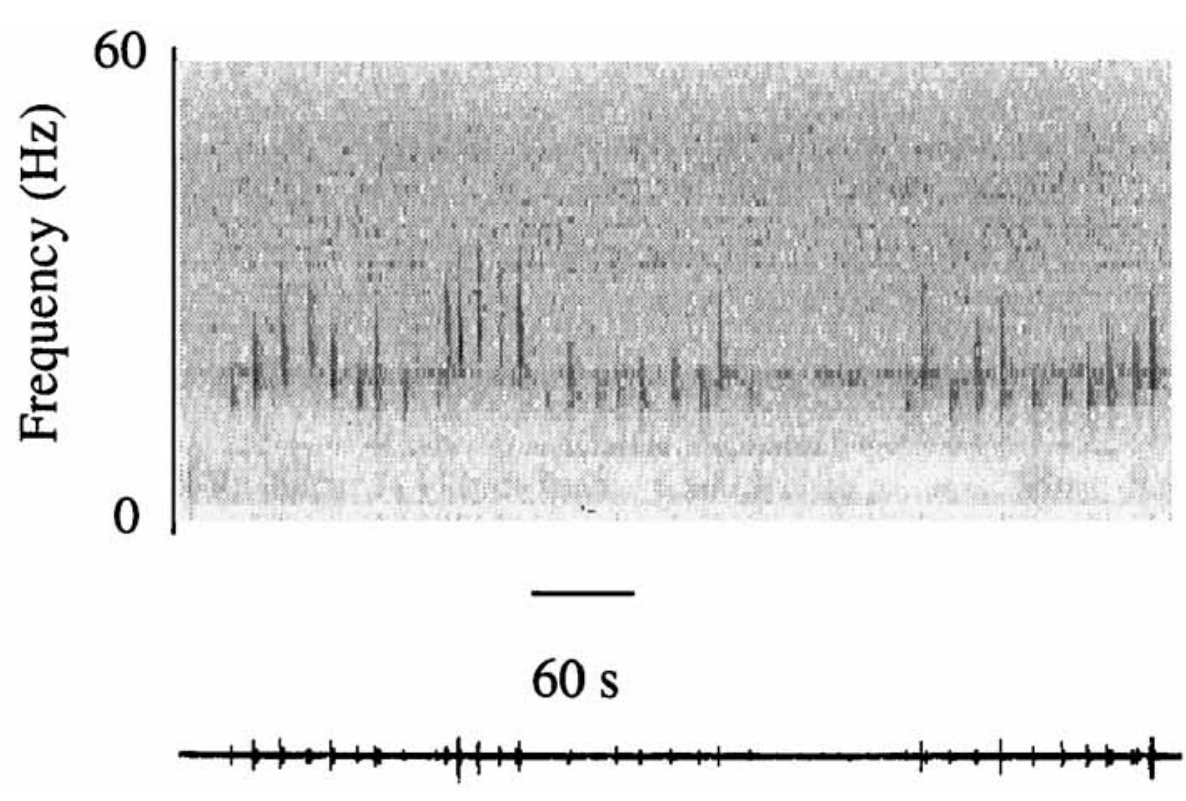

Figure 1. Example spectrogram of fin whale pulses recorded via SOSUS in the North Pacific.

irregular repetition intervals (Fig. 1), similar to fin whale calls recorded from bottom-mounted hydrophones north of Oahu, Hawaii (Thompson and Friedl 1982, fig. 3b) and seafloor seismometers deployed roughly $500 \mathrm{~km}$ west of Oregon (McDonald et al. 1995, fig. 8).

The pilot SOSUS study marked the first attempt to acoustically monitor widely spaced areas in the North Pacific Ocean for fin whale calls over a oneyear period. While $20-\mathrm{Hz}$ pulses have proven a reliable means to passively detect and track fin whales at sea (e.g., Watkins 1981, Watkins et al. 1987, Thompson and Friedl 1982, McDonald et al. 1995), previous studies have been restricted to one locality. While it is generally accepted that passive acoustic methods can complement conventional cetacean survey techniques, long-term application of bioacoustics to the study of whales is still in its infancy. In this report, seasonal variation in reception of calls attributed to fin whales at five areas in the North Pacific are collated with available sighting data and seasonal patterns of productivity for provisional assessment of the utility of such passive acoustic monitoring to the investigation of cetacean ecology.

The Navy's SOSUS consists of a series of bottom-mounted hydrophone arrays that transmit signals to shore-based facilities for signal processing (Wit 1981, Nishimura and Conlon 1994, Richelson 1998). Because SOSUS is still an operational U.S. Navy facility, actual array locations and hydrophone depths are not available. However, a provisional map of SOSUS sites developed by the Navy for use by the Acoustic Thermometry Ocean Climate (ATOC) project (ATOC 1995), is modified here to portray approximate areas monitored for 


\section{North Pacific SOSUS Phones (fictive)}

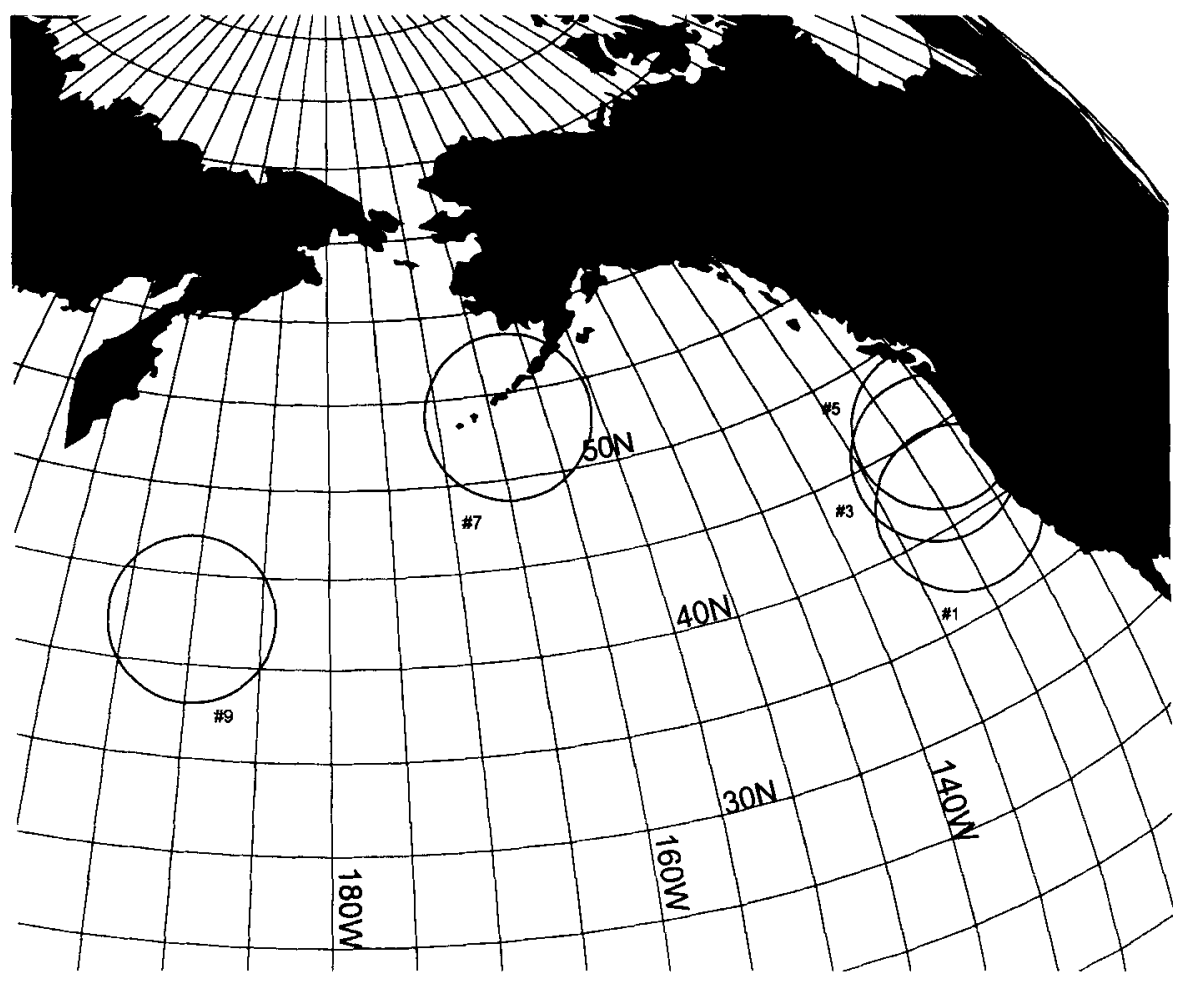

Figure 2. Map of the eastern North Pacific depicting approximate areas monitored by the five SOSUS sites.

whale calls during the pilot study (Fig. 2). In general, the five areas include waters $\sim 500 \mathrm{~km}$ west of the U.S. west coast (sites \#1, \#3, and \#5), south of the Alaskan Peninsula (site \#7), and toward the Emperor Seamounts (site \#9) in the western North Pacific. Sites offshore the U.S. west coast are roughly $185-370 \mathrm{~km}$ apart and so monitor overlapping areas.

During the pilot study, digital data up to $50 \mathrm{~Hz}$ were recorded from a single hydrophone at each SOSUS site and sent to NMML for analysis of whale calls. Because signals were received at high rates, a pseudo-random sampling strategy was adopted to extract portions of tape for analysis. The basic sampling unit was a 10-min segment. Each segment of the 24-h day was sampled once during a 2-wk period. Three of six segments for each hour of the day were randomly drawn from the first week and the remaining three from the second week. Over the course of the pilot study 3,744 segments (i.e., 144 segments/2-wk period $\times 26$ periods) were sampled at each of the five SOSUS sites. Therefore, total call counts for each site represent a 624-h sample, composed of 26 24-h samples, scored bi-weekly over the one-year period.

To process samples, NMMI developed file conversion programs in Turbo 
SITE 1

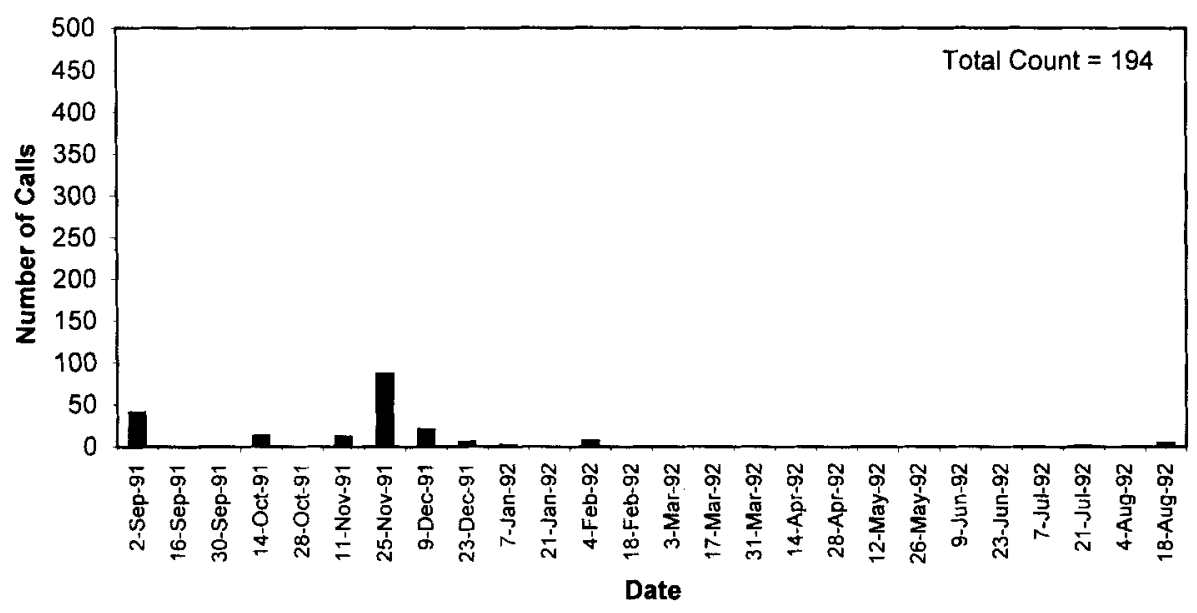

Figure 3. Histograms of fin whale call reception at five SOSUS sites in the North Pacific, September 1991-August 1992. Call counts represent a 60-min sample drawn over a 2-wk period; date reflects midpoint of sampling period.

Pascal (Borland) and Microsoft QuickC for use with SIGNAL (Engineering Design), an acoustic analysis software package. Signals with characteristics that could be identified by eye after spectral analysis were classified by temporal and frequency parameters. The distinctive $1-\mathrm{sec}, 20-\mathrm{Hz}$ calls attributed to fin whales were classified as "Pulse 20" (P20) signals. P20 signals were counted automatically by a SIGNAL-based analysis algorithm trained to recognize a pulse series as a signal event. Post-analysis, P20 signals were randomly checked to verify proper classification. The verification procedure indicated that the algorithm correctly identified P20 signals 93\% of the time. Error was attributed to $7 \%$ of the overall sample when the algorithm was triggered by a single pulse, not likely of biological origin.

A total of 4,274 P20 signals were tallied during the pilot study, with the greatest number of calls at SOSUS site $3(n=1,625,38 \%)$, the fewest at site $1(n=194,4 \%)$, and about the same number at sites 5,7 and $9(n=\sim 800$, $\sim 20 \%$ ). Histograms of counts per 2-wk period at each SOSUS site depict seasonal variation of call reception (Fig. 3). At site 1 , calls were received only between August and February, with a small peak in number in November. Call reception at site 3 was bimodal over the first six months of the study, with the largest peaks in September and October, secondary peaks from December to February, and few the rest of the year. At site 5, call reception was relatively uniform from July through September, with small peaks in November, February, and May. Histograms of call counts at sites 7 and 9 were reversed from each other, with call rates at site 7 high from May through August, and site 9 high from September through November, and few calls at either site the rest of the year. 
SITE 3

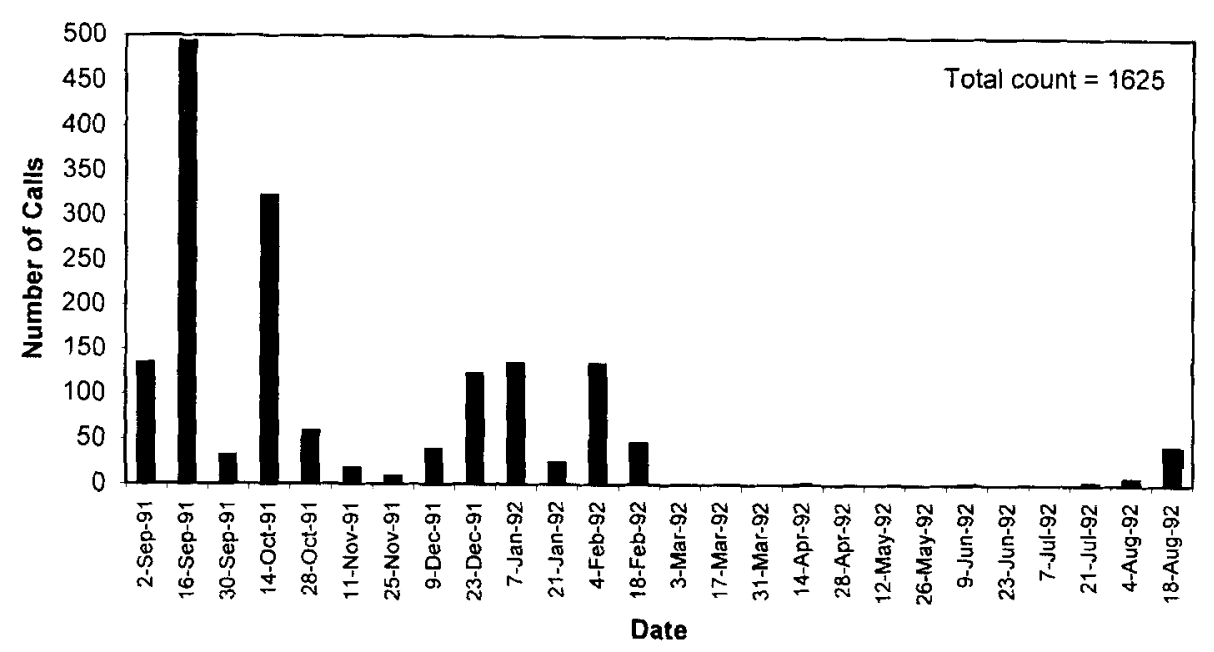

SITE 5

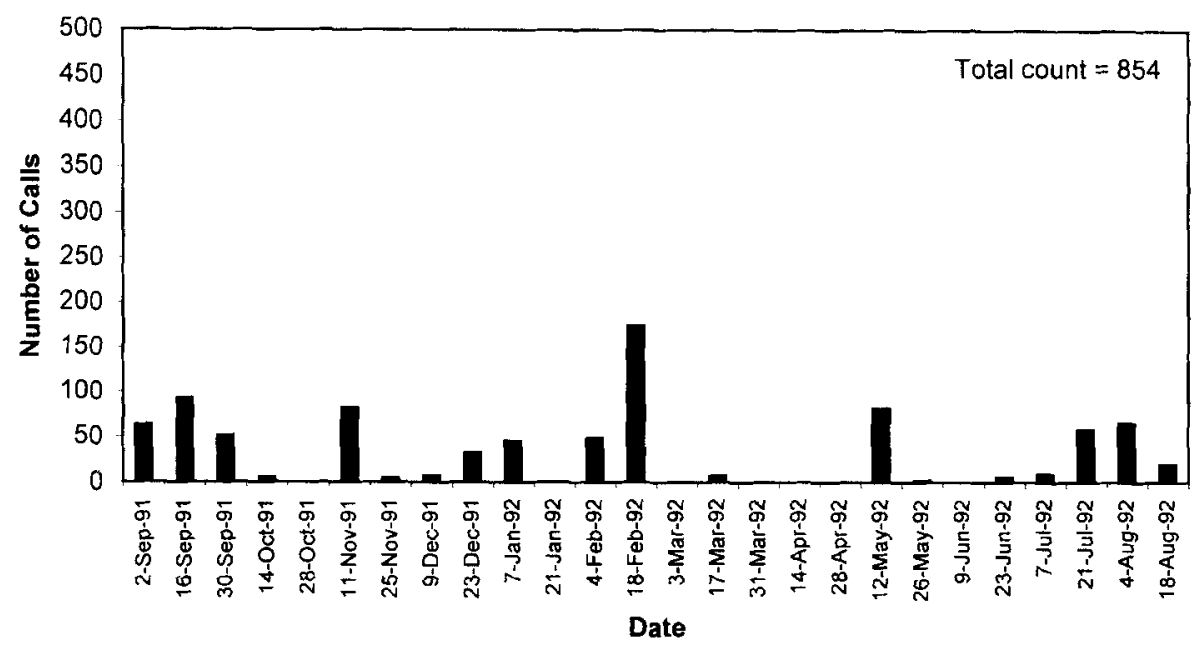

Figure 3. Continued.

Although limited to a $48-\mathrm{h} / \mathrm{mo}$ sample at each site, the reception of calls at the five SOSUS sites can be correlated with fin whale behavioral ecology. Generally, mysticete migrations are presumed to be a means for whales to find and forage upon seasonal dense patches of prey (Nemoto 1970, Katona and Whitehead 1988). Fin whales feed on zooplankton and schooling fish and aggregate where prey densities are high (Piatt and Methven 1992, Piatt $e$ t al. 1989). Concentrations of zooplankton and fishes generally occur in areas of 
SITE 7

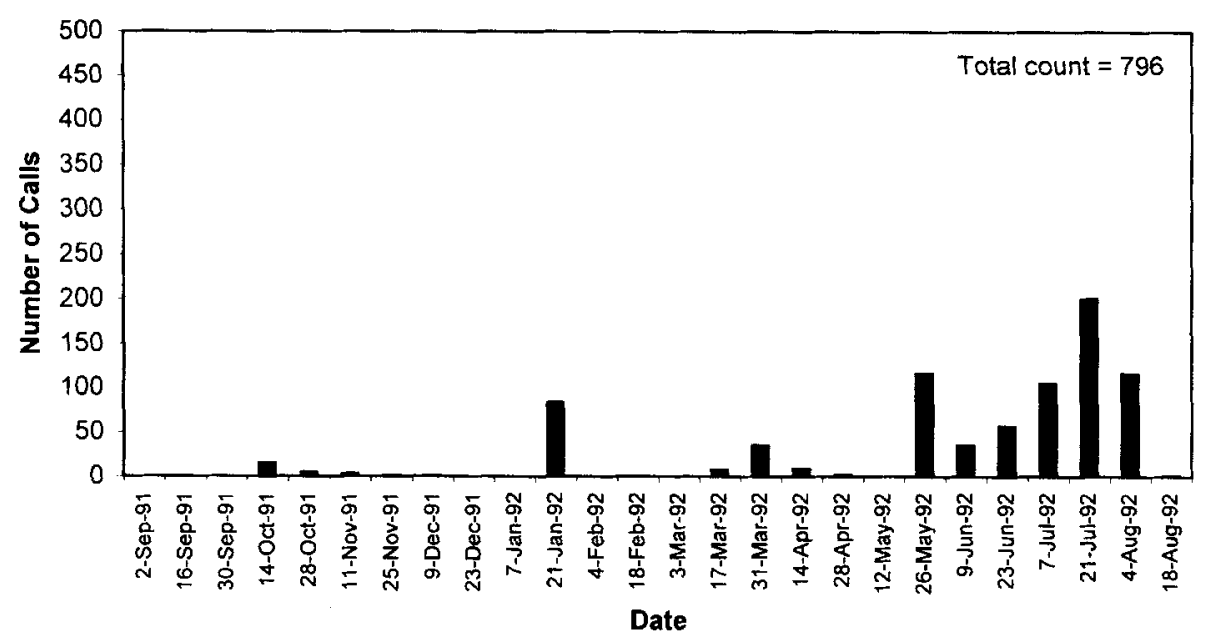

SITE 9

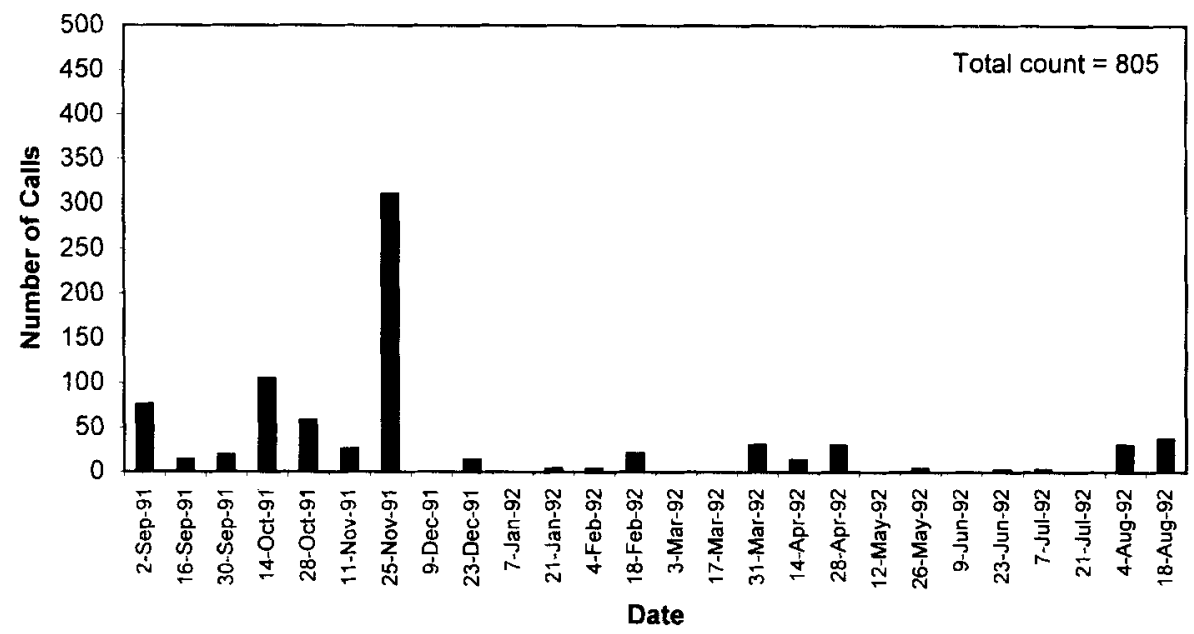

Figure 3. Continued.

high productivity and along oceanic fronts, which are often associated with bathymetric features such as the continental shelf and slope, submarine canyons, and seamounts (Steele 1974, Boehlert and Genin 1987, Dower et al. 1992). Each SOSUS site monitored waters associated with distinctive bathymetric features. Sites 1,3 , and 5 received calls of fin whales occupying continental shelf and slope waters offshore of the U.S. west coast, as well as whales associated with nearby seamounts farther west (e.g., Cobb, Thompson, Brown 
Bear, etc.). SOSUS sites 7 and 9 monitored waters of the Aleutian Trench and toward the Emperor Seamounts, respectively. Further, these areas lie within dynamic oceanographic domains: sites 1,3 , and 5 in the California Current, site 7 in the Alaskan Counter Current, and site 9 in the North Pacific Current.

From vessel and aerial survey sighting data, Barlow (1995) estimated the fin whale population offshore California in summer/fall 1991 to number 935 whales $(\mathrm{CV}=0.635)$, with an estimate of only 49 whales $(\mathrm{CV}=1.012)$ for the winter/spring period (Forney et al. 1995). Sites 1, 3, and 5 monitored broad areas offshore of the U.S. west coast for fin whale calls, including part of the range of the California population. All three of these SOSUS sites exhibited increased call reception from summer through winter, with peaks during fall and winter months. However, because acoustic monitoring is not limited by visibility, weather, or presence of observers, each hydrophone indicated differences in seasonal call pattern not apparent from sighting data. Of note, call counts at site 1 increased to their highest level in November coincident with a lull in call reception at site 3 . Call counts at site 5 exhibited peaks in February (18 February) and May (12 May), when P20 signals were essentially absent at sites 1 and 3 . In addition, the period of consistent, relatively high call counts at site 5 (21 July-30 September) preceded that at site 3 by roughly one month (18 August-28 October).

Call reception patterns at sites 1,3 , and 5 could indicate one fin whale population moving among feeding areas in the eastern North Pacific, or calls from several subpopulations. In the North Atlantic Ocean at least some fin whales were quite site-tenacious, with $30 \%-50 \%$ of identified individuals returning to a specific feeding area in subsequent years (Seipt et al. 1990). Fin whales were seen offshore from Oregon near an area of high bathymetric relief called Newport Valley (near SOSUS site \#1) during aerial surveys conducted between May and September in 1989 and 1990, although sighting rates varied by an order of magnitude between years (Brueggeman 1992). In addition, summertime aggregations of fin whales were seen offshore from the Alaskan Peninsula in waters monitored by SOSUS site 7 (Springer et al. 1996), and sightings from Japanese whaling vessels collated from 1964 to 1990 indicated relatively high fin whale abundance near the Emperor Seamounts (site 9) from May through September (Miyashita et al. 1995).

Patterns of fin whale call reception also generally corresponded to seasonal productivity in the areas monitored. The California Current is a highly dynamic and productive zone, with a strong seasonal presence of cold, nutrientrich, upwelled water in June and July alternating with a warm, stratified period in September and October (Schwing and Mendelssohn 1997). Indeed, a summer-fall influx of blue whales (Balaenoptera musculus) and humpback whales (Megaptera novaeangliae), coincident with the stratified period, has been well documented in recent years (Calambokidis et al. 1996, Schoenherr, 1991). Similarly, in the central North Pacific many mobile marine organisms, including squids, pomfrets, and blue sharks, migrate to and occupy the Transition Zone (site 9) during the fall-winter and the Subarctic Domain (site 7) in the summer-fall (Murata and Hayase 1993, Pearcy 1991) when secondary produc- 
tivity is high due to ample light and warmer water. However, in winter the Transition Zone is the preferred foraging area due to its moderate temperature and smaller seasonal fluctuation in productivity (Springer et al. 1996, Tanaguchi 1981).

Although patterns of fin whale call reception generally concurred with available sighting data and patterns of seasonal productivity, two important caveats must be kept in mind when interpreting the histograms: (1) variation in call reception could be due to both (a) whale occurrence and behavior and/or (b) sound transmission properties of the water column; and (2) the pilot study call counts depict a compilation of 10 -min samples recorded at single hydrophones and therefore represent acoustic "snapshots" of a local area. First, fin whales must have been within acoustic range of a hydrophone for calls to be received. However, the possible effects of behavior on call production and reception are as yet poorly understood. As important, perhaps, are seasonal changes in the physical attributes of the water column that can facilitate or inhibit call reception at the hydrophones by altering sound transmission pathways. Events such as upwelling can affect both whale distribution (via increased prey availability), and sound transmission characteristics of the water. Thus, the strong seasonal upwelling cycles evident in the California and Alaskan currents likely play an, as yet, unquantifiable role in the reception of whale calls at SOSUS sites. Therefore, biological and physical factors, as well as the short sample periods, likely caused fin whale calls to be 'missed' during the pilot study. Further, while data from this pilot study extended the scope of acoustic monitoring to five broadly spaced areas across the North Pacific Ocean, the counts from single hydrophones did not reflect the capability of SOSUS to detect whales at far greater ranges via beam-formed signal processing.

The SOSUS facility is a unique and important tool for monitoring calling whales in the pelagic environment (Cummings and Thompson 1994, Stafford and Fox 1996). SOSUS allows sampling over spatial and temporal scales previously unavailable to marine mammalogists, but potentially of key importance to investigations of cetacean ecology. Standard visual survey techniques will likely remain largely limited to continental shelf waters by logistic and funding constraints. The use of long-range passive acoustics, available with long-term deployments of deep-water hydrophones in pelagic waters in association with broadscale monitoring of oceanic processes, promises to dramatically increase our knowledge of cetacean ecology and population dynamics.

\section{ACKNOWLEDGMENTS}

The manuscript was improved by the review and comments of Bill Watkins (Woods Hole Oceanographic Institution), John Hildebrand (Scripps Institution of Oceanography), David Mellinger (Monterey Bay Research Institute), Mark McDonald, and an anonymous reviewer. Janet Clarke (SAIC) provided graphics and constructive editorial comments. Funding for the pilot study was provided by a contract to NOAA-NMFS/ NMML from the Strategic Environmental Research and Development Program (SERDP), via the Space and Naval Warfare Systems Command (SPAWAR) and the 
Office of Naval Research (ONR). David Bain participated in the study as a postdoctoral fellow at the NMML, under the NOAA/National Research Council Research Associate Program. We thank the U.S. Naval Facility/Whidbey Island, Washington, for access to the SOSUS systems. We also thank Dennis Conlon (SPAWAR), Bob Gisiner (ONR), and Ernie Young (IGPA-ONR) for their assistance with funding, encouragement, and support.

\section{Literature Cited}

Anonymous. 1996. Monitoring whales in the eastern North Pacific Ocean using Navy hydrophone arrays: A pilot study. Prepared by DoC/NOAA: National Marine Mammal Laboratory and Pacific Marine Environmental Laboratory; prepared for DoD/Navy: Space and Naval Warfare Systems Command. 48 pp. + appendix.

ATOC InSTRUMENTATION Group (19 AUTHORS). 1995. Instrumentation for the Acoustic Thermometry of Ocean Climate (ATOC) prototype Pacific Ocean network. MTS/IEEE Oceans '95 Proceedings, Volume 3:1483-1500.

Barlow, J. 1995. The abundance of cetaceans in California waters. Part 1: Ship surveys in summer and fall of 1991. Fishery Bulletin, U.S. 93:1-14.

Boehlert, G. W., and A. Genin. 1987. A review of the effects of seamounts on biological processes. Pages 319-334 in B. H. Keating, P. Fryer, R. Batiza and G. W. Boehlert, eds. Seamounts, islands and atolls. Geophysical Monographs 43, American Geophysical Union.

Brueggeman, J. J., ED. 1992. Oregon and Washington marine mammal and seabird surveys. Final Report prepared for the U.S. Minerals Management Service, Pacific OCS Region, prepared by Ebasco Environmental and Ecological Consulting, Inc. OCS Study MMS 91-0093, variously paginated.

Calambokidis, J., G. H. Steiger, J. R. Evenson, K. R. Flynn, K. C. Baicomb, D. E. Claridge, P. Bloedel, J. M. Straley, C. S. Baker, O. von Ziegesar, M. E. Dahlhem, J. M. White, J. D. Darilng, G. E. Ellis and G. A. Green. 1996. Interchange and isolation of humpback whales off California and other North Pacific feeding grounds. Marine Mammal Science 12:215-226.

Cl.ARK, C. W. 1995. Application of U.S. Navy underwater hydrophone arrays for scientific research on whales. Annex M. Report of the International Whaling Commission 45:210-212.

Cummings, W. C., and P. O. Thompson. 1994. Characteristics and seasons of blue and finback whale sounds along the U.S. west coast as recorded at SOSUS stations. Journal of the Acoustical Society of America 95(5,2):2853.

Dower, J., H. Freeland and K. Juniper. 1992. A strong biological response to oceanic flow past Cobb Seamount. Deep-Sea Research 39:1139-1145.

Forney, K. A., J. Barlow and J. V. CarretTa. 1995. The abundance of cetaceans in California waters. Part II: Aerial surveys in winter and spring of 1991 and 1992. Fishery Bulletin, U.S. 93:15-26.

Fox, C. G., R. P. Dziak, H. Matsumoto and A. E. Schreiner. 1994. Potential for monitoring low-level seismicity on the Juan de Fuca Ridge using military hydrophone arrays. Marine Technology Society Journal 27(4):22-30.

Katona, S., and H. WhItehead. 1988. Are Cetacea ecologically important? Oceanography and Marine Biology Annual Review 26:553-568.

McDonald, M. A., J. A. Hildebrand and S. C. Webb. 1995. Blue and fin whales observed on a seafloor array in the Northeast Pacific. Journal of the Acoustical Society of America 98:712-721.

Mellinger, D. K., And C. W. Clark. 1995. Characteristics of fin and blue whale vocalizations recorded from IUSS in the North and West Atlantic. Page 76 in Abstracts of the Eleventh Biennial Conference on the Biology of Marine Mammals, Orlando, FL. 
Miyashita, T., H. Kato and T. Kasuya, eds. 1995. Worldwide map of cetacean distribution based on Japanese sighting data (Volume 1). National Research Institute of Far Seas Fisheries, Shizuoka, Japan.

Murata, M., AND S. Hayase. 1993. Life history and biological information on flying squid (Ommastrephes bartami) in the North Pacific Ocean. Bulletin of the North Pacific Commission 53 II:147-182.

Nemoto, T. 1970. Feeding pattern of baleen whales in the ocean. Pages 241-252 in J. H. Steele, ed. Marine food chains. University of California Press, Berkeley, CA.

Nishimura, C. E., AND D. M. Conlon. 1994. IUSS dual use: Monitoring whales and earthquakes using SOSUS. Marine Technology Society Journal 27(4):13-21.

PeARCY, W. G. 1991. Biology of the transition zone. Pages 39-56 in J. Wetherall, ed. Biology, oceanography and fisheries of the North Pacific transition zone and subarctic frontal zone. NOAA Technical Report NMFS 105.

Piatt, J. F., and D. A. Methuen. 1992. Threshold foraging behavior of baleen whales. Marine Ecology Progress Series 84:205-210.

Piatt, J. F., D. A. Methuen, A. E. Burger, R. L. Mclagan, V. Mercer and E. Crfelman. 1989. Baleen whales and their prey in a coastal environment. Canadian Journal of Zoology 67:1523-1530.

Richeison, J. T. 1998. Scientists in black. Scientific American 278(2):48-55.

Schoenterr, J. R. 1991. Blue whales feeding on high concentrations of euphausiids around Monterey Submarine Canyon. Canadian Journal of Zoology 69:583-594.

Schwing, F. B., AND R. Mendelssohn. 1997. Increased coastal upwelling in the California Current System. Journal of Geophysical Research 102:3421-3438.

Serpt, I. E., P. J. Clapham, C. A. Mayo and M. P. Hawvermale. 1990. Population characteristics of individually identified fin whales, Balaenoptera physalus, in Massachusetts Bay. Fishery Bulletin, U.S. 88:271-278.

Springer, A. M., C. P. McRoy and M. V. Flint. 1996. The Bering Sea Green Belt: Shelf-edge processes and ecosystem production. Fisheries Oceanography 5:205223.

StafFord, K. M., And C. G. Fox. 1996. Occurrence of blue and fin whale calls in the North Pacific as monitored by U.S. Navy SOSUS arrays. Journal of the Acoustical Society of America 100:2611.

Steele, J. H. 1974. The structure of marine ecosystems. Harvard University Press, Cambridge, MA.

Tanaguchi, A. 1981. Plankron productivities in the Pacific subarctic boundary zone: Food conditions of the migrating pelagic fishes. Research Institute of North $\mathrm{Pa}$ cific Fisheries. Hokkaido University, Special Volume 1:23-35.

Thompson, P. O., AND W. A. Friedl. 1982. A long term study of low frequency sounds from several species of whales off Oahu, Hawaii. Cetology 45:1-19.

Thompson, P. O., L. T. Findley and O. Vidal. 1992. 20-Hz pulses and other vocalizations of fin whales, Balaenoptera physalus, in the Gulf of California, Mexico. Journal of the Acoustical Society of America 92:3051-3057.

Thomson, D. H., and W. J. Richardson. 1995. Marine mammal sounds. Pages 159204 in W. J. Richardson, C. R. Greene, Jr., C. I. Malme and D. H. Thomson, eds. Marine mammals and noise. Academic Press, San Diego, CA.

WatKINS, W. A. 1981. Activities and underwater sounds of fin whales. Scientific Reports of the Whales Research Institutes, Tokyo 33:83-117.

Watkins, W. A., P. Tyack and K. E. Moore. 1987. The $20-\mathrm{Hz}$ signals of finback whales (Balaenoptera physalus). Journal of the Acoustical Society of America 82: 1901-1912.

WIT, J. S. 1981. Advances in antisubmarine warfare. Scientific American 244(2): $31-41$.

Sue E. Moore, SAIC, Maritime Services Division, 3990 Old Town Ave., Suite 105A, San Diego, California 92110,U.S.A.; e-mail: sue_moore@cpqm.saic.com; 
Kathleen M. Stafford, NOAA-PMEL/Oregon State University, Hatfield Marine Science Center, 2115 S.E. OSU Drive, Newport, Oregon 97365, U.S.A.; Marilyn E. Dahlheim, NOAA-NMFS/AFSC, National Marine Mammal Laboratory, 7600 Sand Point Way NE, Seattle, Washington 98115, U.S.A.; CHRISTOPHER G. Fox, NOAA-PMEL/Oregon State University, Hatfield Marine Science Center, 2115 S.E. OSU Drive, Newport, Oregon 97365, U.S.A.; Howard W. Braham, NOAA-NMFS/AFSC, National Marine Mammal Laboratory, 7600 Sand Point Way NE, Seattle, Washington 98115, U.S.A.; JefFrey J. PolovinA, NOAA-NMFS/SWFSC, Honolulu Laboratory 2570 Dole St., Honolulu, Hawaii 96822, U.S.A.; DAvid E. BAIN, 4680 Limestone Point Road, Friday Harbor, Washington 98250, U.S.A. Received 10 March 1997. Accepted 25 July 1997. 